\title{
Attitudes of Communities in Rural Areas towards the Development of Wind Energy
}

\author{
Mirosława Witkowska-Dabrowska *(D), Natalia Świdyńska (D) and Agnieszka Napiórkowska-Baryła \\ Faculty of Economic Sciences, University of Warmia and Mazury in Olsztyn, M. Oczapowskiego 4, \\ 10-719 Olsztyn, Poland; natalia.swidynska@uwm.edu.pl (N.Ś.); agnieszka.baryla@uwm.edu.pl (A.N.-B.) \\ * Correspondence: m.witkowska@uwm.edu.pl; Tel.: +48-606-488-745
}

Citation: Witkowska-Dabrowska, M.; Świdyńska, N.;

Napiórkowska-Baryła, A. Attitudes of Communities in Rural Areas towards the Development of Wind Energy. Energies 2021, 14, 8052. https://doi.org/10.3390/en14238052

Academic Editors: Algirdas Jasinskas, Behnam Zakeri and

Renata Marks-Bielska

Received: 5 October 2021

Accepted: 24 November 2021

Published: 1 December 2021

Publisher's Note: MDPI stays neutral with regard to jurisdictional claims in published maps and institutional affiliations.

Copyright: (c) 2021 by the authors. Licensee MDPI, Basel, Switzerland. This article is an open access article distributed under the terms and conditions of the Creative Commons Attribution (CC BY) license (https:// creativecommons.org/licenses/by/ $4.0 /)$.

\begin{abstract}
The objective of the study was to demonstrate attitudes towards wind energy facilities in the area of the Korsze Commune. The results of the study were processed using structure indices calculated from the respondents' answers, which were analyzed in terms of social and economic factors. The study revealed that both the NIMBY syndrome and the lack of civic engagement influence attitudes towards renewable energy technologies in rural areas. The NIMBY ("not in my backyard") term describes negative public attitudes towards proposed development projects. However, some trends towards more pronounced attitudes can be observed, depending on socioeconomic conditions. The research results imply that the measures taken to promote renewable energy technologies should be designed differently depending on the socioeconomic situation of the targeted audience. Young people might be reached via social media appropriate to their age, and through campaigns promoting local investments. For older people, traditional ways of communication can be used, but the information transmitted should include specific benefits for the whole society as well as for individual households. The conducted research revealed that, despite the fact that many authors deny the occurrence of NIMBY syndrome in relation to the wind energy, the NIMBY problem has occurred in the Korsze Commune. The biggest challenge in the survey was the unwillingness of the residents to participate in it, which only confirms the lack of social involvement.
\end{abstract}

Keywords: renewable energy sources; wind energy; sustainability

\section{Introduction}

In 2009, the International Renewable Energy Agency was founded to promote renewable energy sources. It currently brings together more than 180 countries, promoting renewable resources and technologies [1]. Renewable energy sources provide an alternative to fossil fuels and contribute to reducing greenhouse gas emissions. By 2030, 40\% of energy consumption in the European Union is expected to come from renewable sources [2].

Among the EU documents regulating the issue of renewable energy sources are numerous directives that are being replaced by successive ones:

- Directive 2009/28/EC of the European Parliament and of the Council of 23 April 2009 on the promotion of the use of energy from renewable sources and amending and subsequently repealing Directives 2001/77/EC and 2003/30/EC.

- Directive 2001/77/EC of the European Parliament and of the Council of 27 September 2001 on the promotion of electricity produced from renewable energy sources in the internal electricity market.

- Directive 2003/30/EC of the European Parliament and of the Council of 8 May 2003 on the promotion of the use of biofuels or other renewable fuels for transport.

- Directive (EU) 2018/2001 of the European Parliament and of the Council of 11 December 2018 on the promotion of the use of energy from renewable sources.

Poland has been a member of the European Union since 2004 and the Renewable Energy Agency since 2009, thus obliged to implement their policies. 
The wind power today supplies $12.5 \%$ of the electricity in Poland. In 2015, the Parliament of the Republic of Poland passed the first act on renewable energy resources [3], but the first wind turbines were constructed in Poland as early as in 2001. The year 2016 marks the entry into force of the Act on Wind Farm Investments [4], which stipulates that the distance from a wind farm to a residential building must be no less than ten times the height of the wind turbine in question. The key argument in favor of this provision was public protest.

When analyzing the classical and contemporary location theories, it is possible to distinguish certain dependencies between the location of wind power plants and selected theories of the location of enterprises. Wind power plants need to be located on sites with most suitable wind conditions. Because wind, as an energy resource, cannot be transported, its conversion into electric power must take place in the area where it occurs. The transport of the product (electricity) does not involve a high expenditure (the cost of connecting to an electricity grid is about $8-20 \%$ of the total investment outlays).

In the view of the above, the location of a wind power facility should be guided by the availability of the resources. In 1909, Weber distinguished a resource orientation (on a site where the raw material is present) or a market orientation (where the market for produced goods is), depending on the value of the material index [5]. However, contemporary researchers point to the fact that wind power plants are also located in sites with less favorable wind conditions [6]. This is made possible by increasingly advanced technologies. In Poland, the law allows the development of wind power plants only in rural areas or in marine areas.

Another location theory with discernible implications for the location of wind farms is the behavioral theory $[7,8]$. After all, the investor depends on decisions made by administrative organs and on the attitude of the local community. All investments of this type first require provisions in the local spatial development plan but are also submitted to the social discussion. Moreover, incomplete information on the actual situation encourages decisionmakers to imitate the competition and locate the investment in the areas which others already chose and became familiar with. The reason is insufficient knowledge on the distribution of wind power resources. According to the behavioral approach, the decision-maker looks for locations that are satisfactory, rather than optimal. Thus, a location that is finally chosen is a possible one. The investor with the greatest database of information and the capacity to process it chooses the optimal location situated in the area with the largest wind power resources. Investors with less information will choose a satisfactory location [9]; however, conflicts can arise here.

Sustainable and permanent development calls for deep restructuring of the fuel and energy sector [10]. Bielski et al. [11] demonstrated that coal remains the basic resource for energy generation in Poland. The relationship between sustainable development and renewable energy resources in the EU member states, seen from a new perspective achieved by hierarchical clustering, was explored by Włodarczyk et al. [12]. They concluded that in 2019, Poland and five other countries in the D-2019 cluster possessed the key defining value of having the lowest average share of the renewable energy in the heating and cooling sectors. However, investments in the renewable energy are the most common targets of social protests. Interestingly, residents, in general, opt for constructing such developments, but not near their place of residence. This is known as the NIMBY (not in my backyard) syndrome [13]. The NIMBY term describes negative public attitudes towards proposed development projects. Although academic research increasingly often discards NIMBYism as a useful approach to understanding why society opposes certain investments, this discourse continues to feature strongly in the public debate [14]. Increasingly often, discussions revolve around the issues of a lack of civic engagement. The participation of a society is of key importance in conflict management. Studies show that the engagement of a community, the extent to which it is engaged, the attitude to one's engagement, and the time dedicated to civic activity are among the influential factors [15]. O'Hare et al. [16] long ago pointed out that it is difficult to talk about a homogeneous "public opinion". Even the most 
widely opposed location, once the investment has been completed, will bring a benefit to some people, however few they may be.

Wind farms are planned and built in nonurbanized areas, that is, mostly in rural areas. Some researchers even suggest that rural areas are a barrier to the development and modernization of a country due to their residents' traditional and conservative beliefs. However, such conclusions can result from a one-sided approach to research on civic activity in the countryside [17]. It may happen that representatives of a local government do not take into account the needs and demands of their electorate. Some believe they are the rulers rather than representatives of their local community and therefore their decisions must be respected. As a legacy of the communist era, it is still common to distinguish between "us" and "them", "them" being "corrupted" representatives of the authorities minding their own business and making incomprehensible decisions [18]. Therefore, it is worth considering what influences attitudes towards wind energy.

Relying on a case study in the municipality of Korsze, this research provides new value-added in the form of conclusions. It allows to answer the question of how to promote renewable energy in a specific location in order to fulfil the commitments to achieve sustainable and lasting development.

This study presents only a small part of the problem; however, the Korsze Commune is located in an area with very good wind conditions for the wind energy development. Therefore, it is a good example of a well-localized investment, which may cause discomfort to the commune's residents due to local impacts.

The literature review refers to the most frequently indicated problems in rural areas related to the development of the renewable energy sources connected with social acceptance. The development of wind energy in the world, Europe, and Poland is briefly described. The Materials and Methods chapter describes the research subject, the research sample, and the demographic characteristics of the respondents.

The Results and Discussion section provides a brief theoretical introduction and analysis of the survey results, including a discussion. The last chapter is a summary of the conclusions of the research, the verification of the hypothesis, and the difficulties encountered during the research.

\section{Literature}

The world's technologically exploitable wind energy resources are estimated to be approximately 53,000 TWh/year. Such an amount of energy would be sufficient to satisfy annual global energy needs $[19,20]$. Over the last 20 years, the achievable capacity of a single wind power plant increased almost 20 times, while the cost of producing a unit of energy decreased five times. By 2040, the cost of producing energy from onshore wind farms will have fallen by $41 \%$ [21]. Changes in the development of turbine technologies allow for more efficient use of wind power and a longer lifetime [1,22-24]. Estimated annual capacity additions from wind power globally account for $50 \mathrm{GW}$ to $74 \mathrm{GW}$ of solar PV capacity and $36 \mathrm{GW}$ of other renewables [25]. Despite the COVID-19 pandemic, the world will add more than $260 \mathrm{GW}$ of renewable energy capacity in 2020, beating the previous record by almost $50 \%$.

The wind energy almost doubled in 2020 compared to 2019 (111 GW compared to $58 \mathrm{GW}$ last year). China added $72 \mathrm{GW}$ of new capacity, followed by the United States of America (14 GW). Ten other countries added more than $1 \mathrm{GW}$ of wind capacity in 2020. Offshore wind increased its share of the total wind capacity in 2020 to about 5\% [26]. With the rapidly increasing power, the power electronic technologies used in wind turbines (WTS) have also changed dramatically in the last 30 years [27-35]. The only problem with the rapid wind energy development may be rare earth elements (REEs), such as neodymium $(\mathrm{Nd})$, used in permanent magnets (PMs) in generators [36]. In some wind development scenarios, demand for REEs could restrain supply or lead to dependence on potentially uncertain supplies $[36,37]$. 
Onshore wind development is also an important part of the European transition towards an energy system based on renewables and low-carbon resources. Considering the sociotechnical conditions that limit $54 \%$ of the total land area in Europe, a nominal capacity of 52.5 TW of the untapped onshore wind potential in Europe was demonstratedequivalent to $1 \mathrm{MW}$ for every 16 people in Europe, the supply that would be sufficient to meet global energy demand in all sectors from now until 2050 [38]. Wind energy is considered by numerous studies to be a critical factor in achieving the $100 \%$ national renewable energy obligation of the European Commission's Energy Strategy $2050[39,40]$. Research results [38] suggest that Europe has much greater potential for onshore wind energy than previously thought. The total area of the European countries is about 1,0737,064 $\mathrm{km}^{2}$, whereas the European part of Russia $\left(3,960,000 \mathrm{~km}^{2}\right)$ is the largest onshore area and Malta $\left(316 \mathrm{~km}^{2}\right)$ the smallest. Within the European onshore area, $5,841,503 \mathrm{~km}^{2}$ is a restricted use area, meaning that the remaining $4,895,560 \mathrm{~km}^{2}$ could be used for wind project development. If this could be fully realized, the turbine density in Europe would increase from $1 \mathrm{MW}$ per 4564 inhabitants to $1 \mathrm{MW}$ per 15 inhabitants (approximately). Poland is in the range of potential turbine density of $1 \mathrm{MW}$ per 4000 to 8000 inhabitants [41]. However, the authors of the study emphasize that it is intended to serve decision-makers and may be criticized and questioned as to the practicality and profitability of installing wind turbines at the density level used in the proposed model. It is believed that at the $40 \%$ level, onshore wind power has been challenged by the NIMBY opposition in Europe [42]. For the potential of onshore wind power, the study merely suggests that the horizon is still bright for this particular wind power application and that European aspirations for a 100\% renewable grid are technologically within our collective reach [38]. Several European countries have already achieved relatively high levels of wind energy penetration, including Denmark (42\%), Portugal (23.2\%), Ireland (23\%), Spain (18\%), Germany (13.3\%), and the UK $(11 \%)$. Other major wind markets also present a significant share of wind power generation, including the United States (4.7\%), China (33\%), and Brazil (3\%). An important milestone is that on 3 November 2013, a record was set in Denmark, where wind energy production exceeded energy consumption at the national level for the first time [34]; this now happens regularly.

In Poland, there are more than 1200 installations using wind as a renewable energy source. Their installed capacity is over $5900 \mathrm{MW}$, which is about $65 \%$ of the installed capacity of all types of RES installations working in Poland. Nearly 160 further wind installations are under construction, with a total installed capacity of approximately $2500 \mathrm{MW}$. The amount of energy produced from wind sources and fed into the Polish power system is steadily growing. In 2020, they produced $14,174 \mathrm{GWh}$ of energy compared to $13,903 \mathrm{GWh}$ in 2019. Wind energy accounted for about $10 \%$ of the energy consumed in the country in 2020. The development of onshore wind energy capacity in Poland was restricted in 2016, when a law was introduced prohibiting the construction of turbines within $2 \mathrm{~km}$ of buildings or forests, thus excluding $99 \%$ of Poland. The Korsze Commune is located in a zone of very favorable wind conditions [42].

The NIMBY ("not in my backyard") and YIMBY ("yes in my backyard") terms describe successively negative and positive public attitudes towards proposed development projects [43]. The NIMBY is a pejorative term, indicating human parochialism and irrationality [44-48]. This is because it is a negative approach to development projects that aim to meet social needs. The affront is caused by reasons such as concerns about the nuisance of the development, its danger, and unattractiveness, and may ultimately affect the reduction of property values $[49,50]$.

The term NIMBY emerged in the 1980s, due to protests by local communities against the location of a hazardous waste dump in their neighborhood. Since then, protests over the location of various types of facilities have begun to be addressed: wind farms [14,50-53], livestock farms [54], prisons [55], hazardous waste landfills [56,57], biogas plants [58,59], homeless assistance centers [60,61], renewable energy [62,63], and nuclear reactors [64-67]. 
In rural areas located in Poland, a large number of protests concern renewable energy investments. It should be noted, however, that Poland is obliged, according to the assumptions of the European regional policy, to decarbonize the energy sector. It is therefore necessary to intensively implement unconventional energy sources. The most numerous protests in all regions of the country have been triggered by wind energy plants [53]. Despite the high support for wind energy declared by the Polish society [68], the construction of specific facilities causes numerous social protests. This should be considered a typical example of the NIMBY syndrome [53].

Although many authors have criticized and pointed out the exaggeration of the NIMBY syndrome [14,69-72], many authors continue to study this phenomenon without denying its scale and the very fact of its existence [73-75], also in relation to renewable energy sources $[62,63,76,77]$. The NIMBY syndrome is also being studied for social behavior research in the era of the global COVID-19 pandemic [78,79].

The NIMBY syndrome is a manifestation of local community activism in the sphere of public life. It manifests itself when a planned investment is unwanted by the public. The literature on the subject uses the term social participation [80].

The economic practice indicates a high level of public participation in the management of the environment, landscape, and space [81]. This is because the local community has knowledge about the inhabited space. While this should be considered colloquial, its importance in many cases goes beyond professional knowledge [82-84]. Considering public participation in relation to the NIMBY syndrome is justified by the fact that the location of investments considered controversial should be preceded by an open dialogue between all interested parties [53]. This is because it allows decision-makers to make the right decision.

The local population has many tools allowing them to have a real impact on the shaping of public space and the implementation of local investments [85]. The most common example is participation in elections. Local influence is based, among others, on the possibility to participate in public consultations [86,87].

However, many research works indicate that civic engagement in local affairs is insufficient [88-92]. Every citizen should discover the basic determinants of involvement in social life. One of the criteria that allows evaluating social engagement is the category of participation. In the anthropological sense, participation is understood as a specific way of being in social life, through which a person not only acts in it, but also testifies with his/her whole life. Participation, properly understood, includes the complementary attitudes of solidarity and opposition, which capture the inbreeding and outward dimension of human existence. Joining others, a person does not cease to be an individual subject $[93,94]$. A man as a social being takes actions as a member of his own group and in the interest of other people. In the context of a democratic system, it is justified to distinguish civic activity as a separate type of social activity. Theoretical analysis of this activity makes it possible to distinguish and describe four forms of it, such as social involvement, social (civic) participation, individual political activity, and participation in governance. This model can be used as a reference point in interdisciplinary research and theoretical and empirical analyses that describe the activities of people pursuing social interests [95]. An observed trend in civic participation is to base it more on individuality than on group cooperation. Research confirms a significant relationship between the level of civic participation and the independent variables: gender, age, place of residence, and family relations. Research conducted in the Slovak Republic indicates a deficit of civic activity among young people, indicating that Slovak society should also focus on ways to promote more active political participation of young people, based on group cooperation and their involvement in voluntary activities in social movements and organizations [96].

\section{Materials and Methods}

\subsection{Objective and Hypotheses}

The objective of the study was to demonstrate attitudes towards wind energy facilities in the area of the Korsze Commune. 
A hypothesis was set: socioeconomic factors shape attitudes towards renewable energy.

\subsection{Selection of the Research Sample}

The study covered the rural areas of the Korsze Commune, in the County of Kętrzyn, in the provinces of Warmia and Mazury. The main branch of the economic development of the rural and urban Korsze Commune is agriculture. Agricultural land covers nearly $80 \%$ of the municipality's area, including $74.1 \%$ (14,426 ha) of arable land, $7.7 \%$ (1510 ha) of meadows and pastures, and 15.8\% (3076 ha) of orchards. They lie on good soils, classified as a third and fourth soil valuation class in the Polish soil classification system. There is a wind farm in the Korsze Commune, launched in 2011, as well as over 35 wind turbines. In 2020, the rural part of the commune was inhabited by 5400 persons aged 18 and over, including $58 \%$ of women. The rationale for selecting this commune for our study is the recently more intensive development of photovoltaic power plants in regions with low insolation, such as Northeastern Poland [6].

Within the Warminsko-Mazurskie Voivodeship, a clear differentiation in the planning approach towards wind energy development was observed. Many administrative units are interested in rapid development of this energy sector, seeing it as a great material benefit (e.g., Korsze Commune) [97]. Fragments of Korsze Commune have already prepared local spatial development plans with an indication of such development. It is also provided for in the stage of conditions and directions of spatial development of the commune. It is in accordance with the Concept of the RES development in the Warminsko-Mazurskie Voividship.

The survey was conducted in July 2021, using a paper questionnaire composed of nine questions and an index. The survey questionnaire was distributed using a snowball sampling method among a representative sample of residents in the study area. The minimum size of the sample was calculated using the following Equation (1):

$$
n=\frac{u^{2} x p(1-p)}{e p^{2}}
$$

where:

$n$-size of the sample.

$u$-coefficient dependent on the assumed level of confidence; at the confidence level $0.95, u=1.96$.

$e p$-prediction error is assumed to be $+/-5 \%(e p=0.05)$.

$p$-relative frequency (structures of $p$ trait).

Considering the above, the minimum size of the sample was 748 persons. One thousand survey questionnaires were distributed. The questionnaire was filled in by 800 people, of which $54 \%$ were women (Table 1 ).

Table 1. Demographic characteristics of respondents (\%).

\begin{tabular}{|c|c|c|}
\hline \multirow{2}{*}{ Gender } & Females & 54 \\
\hline & Males & 46 \\
\hline \multirow{4}{*}{ Age } & $18-25$ & 11 \\
\hline & $26-36$ & 30 \\
\hline & $37-50$ & 31 \\
\hline & Over 50 & 28 \\
\hline \multirow{4}{*}{ Education } & Primary or mid-secondary & 9 \\
\hline & Vocational & 17 \\
\hline & Secondary & 40 \\
\hline & Higher & 34 \\
\hline
\end{tabular}


Table 1. Cont.

\begin{tabular}{ccc}
\hline \multirow{2}{*}{$\begin{array}{c}\text { Number of people in the common } \\
\text { household }\end{array}$} & 1 & 12 \\
\cline { 2 - 3 } & $2-3$ & 45 \\
\cline { 2 - 3 } & $4-5$ & 38 \\
\hline \multirow{2}{*}{$\begin{array}{c}\text { Monthly disposable income per capita } \\
\text { in a household (PLN) }\end{array}$} & At least 6 & 16 \\
\cline { 2 - 3 } & Less than 1600 & 29 \\
\cline { 2 - 3 } & $1601-1800$ & 55 \\
\hline
\end{tabular}

Source: the authors, based on own research.

\subsection{Methods for Developing Survey Results}

The results of the survey were processed using the structure indicators calculated based on the indications given by the respondents, which were analyzed in terms of the social and economic factors. The age and education were distinguished as social factors; the economic factors included the disposable income per person in a household. In addition, the analyses accounted for the gender of respondents and the number of persons in their households $[4,5]$. Because of a small study probe, the calculation of correlations was dismissed.

\section{Results and Discussion}

\subsection{Theoretical Introduction}

There are several criteria applied to the division of types of conflicts, including the time when residents learn about the planned investment and engage in actions to block it. It is possible to distinguish conflicts which begin

- In the early stage of planning an investment (before starting administrative or planning procedures).

- At the stage of developing planning documents (when the development is sited based on a local plan).

- At the stage of making an environmental impact assessment; after obtaining an environmental impact decision.

The study carried out by Bednarek-Szczepańska and Dmochowska-Dudek [13] shows that conflicts most often arise at the stage of the development of the planning documents, and in the case of investments located based on a decision about land development (or a decision on location of a public purpose investment) - while the environmental assessment is being made. The designation of land as a site for the development of a wind farm depends on the content of the local spatial development plan. A local spatial development plan is socially consulted before approval. However, at this stage, the rural population is often not involved in the discussion and its assumptions. Only at the moment of the planning of the investment or even when starting the construction, does the conflict escalate. In the Warminsko-Mazurskie Voivodeship, it was found that the most frequent NIMBY conflicts concerning wind energy are those of local residents [53].

Studies indicate that even in $1 / 4$ of cases, the municipal authorities proceeded to amend or enact new planning documents in order to enable the construction of the investment [53]. On the other hand, the requirement to agree with the public is considered nonbinding by law. This means that the investment planning must be consulted with the public, but in the case of lack of public acceptance, the investment may be carried out anyway.

In such cases, the commune authorities, when deciding on the investment, consider the sequence of appeals and complaints and invalidation of the decision, thus taking the side of the opposing residents. This prolongs the process or de facto makes it impossible to proceed with the investment.

Having entered into force in 2016, the provisions of the Act on Investments in Wind Power Farms [4] do not allow other options for locating a wind farm than on the grounds of 
a given local land spatial development plan. Meanwhile, the act defines a wind power plant as a renewable energy facility composed of a building construction defined as a building in the Building Law, and technical devices, including technical elements where electricity is generated from wind power, of a capacity greater than the capacity of a micro-installation as specified in Article 2 point 19 of the Act on Renewable Energy Resources of 20 February 2015 [3]. It can therefore be a single turbine of a capacity as stipulated by law. Wind farms are located in nonurbanized areas because of the required distance to buildings. Most land in nonurbanized areas is designated as an agricultural land and is located in the countryside. It is possible to use such land for constructing turbines or wind farms as long as the local spatial development plan contains an appropriate provision. To obtain the permission, an investor must proceed through a formal and legal procedure, which is composed of several stages and lasts for 6 to 12 months.

This is a certain barrier to investors, as such plans were not yet developed and adopted in a large part of Poland. Moreover, because the procedure for adopting a local plan is a multistage, lengthy, and expensive process, many communes do not even expect to start the preparation of such documents in the nearest future. Until 2016, in the absence of local spatial development plans, investors engaged in the construction of wind power facilities obtained decisions on development conditions, and this document enabled them to apply for building permits to raise wind farms. Once the new law was adopted in 2016, this procedure was no longer applicable. However, there is a certain advantage to this situation, namely, each change in the plan must be accompanied by discussions with a given community taking place as early as the stage of planning. In consequence, any potential environmental conflicts can be anticipated.

There is an unwavering problem of the society's disinclination to participate in a civic debate caused by the unwillingness to participate in any activity as long as the matter does not directly affect the person concerned. The literature dealing with the NIMBY syndrome mostly originates from Western countries, although there are now comparative studies completed in other parts of the world. In Shanghai and Hong Kong, for example, research related to on the influence of the society on the environmental conflicts instigated by the NIMBY syndrome was completed. In both cases, it was detected that the society did not participate in investment projects at the stage of planning and/or deciding to proceed with a project. In continental China, it was determined that manipulations, a deficit of civic activity, and the society's delayed participation in making decisions adversely affected the society's willingness to accept the project. Based on results of these case studies, the engagement of key stakeholders, greater extent of the society's participation, and an approach involving targeted participation, as well as timely contribution to the process of planning an investment, are recommended [15]. Empirical studies suggest that, in practice, it is difficult to find persons who support renewable energy but are motivated by the calculation of personal costs and benefits to oppose local siting of an investment $[72,98,99]$ which points to the role of one's attachment to a place, to symbolic interpretations of both the place and the technology [100], and to several political, social, and environmental values [101] that affect attitudes of opposition or support.

Burningham et al. [102] quote results of numerous studies exploring the issue of opposition to renewable energy developments $[51,52,98-101,103]$. The same as in the wider literature, there is a consensus that NIMBYism is an inaccurate and unhelpful way of describing opposition to siting. Furthermore, the characteristics of planning and decision-making processes, as well as the rapport between local communities and persons responsible for the planning, building, and management of investments, have been recognized in the wider literature $[104,105]$ as playing a role. Based on such investigations, Gibson argues that "it is time for progressive activists and critical sociologists to begin living without NIMBY" [106]. Although academic studies increasingly discard NIMBYism as a precise or useful way of understanding opposition, this discourse remains powerful in public debate (cf. Wolsink). Finally, and importantly for us, both positions of literature contain parallel calls for studies which would examine these discourses in practice. The calls for the research that would 
focus on using descriptions of the NIMBY phenomenon in general have been occurring for some time now $[102,106,107]$, but, recently, in connection with the siting of RET facilities, Bell et al. suggest that "it is important to study the discursive use of "NIMBY" in wind energy politics" [99]. Wright and Nerlich [108] conceptualize deficit models as "culturally available interpretative repertoires" and claim that "work is required" ... "to discover how widespread the use of the deficit model actually is".

\subsection{Support of the Korsze Commune Society for Wind Energy}

4.2.1. Representative Research Sample

In our study, most respondents (38.75\%) declared to support the development of renewable energy technologies (RETs). A fifth of the respondents did not support their development, including $15 \%$ who strongly opposed it.

Over $62 \%$ of the respondents supported the construction of wind power plants $(22.5 \%$ strongly supported), while $22.5 \%$ did not support it (over 16\% strongly opposed) (Figure 1).

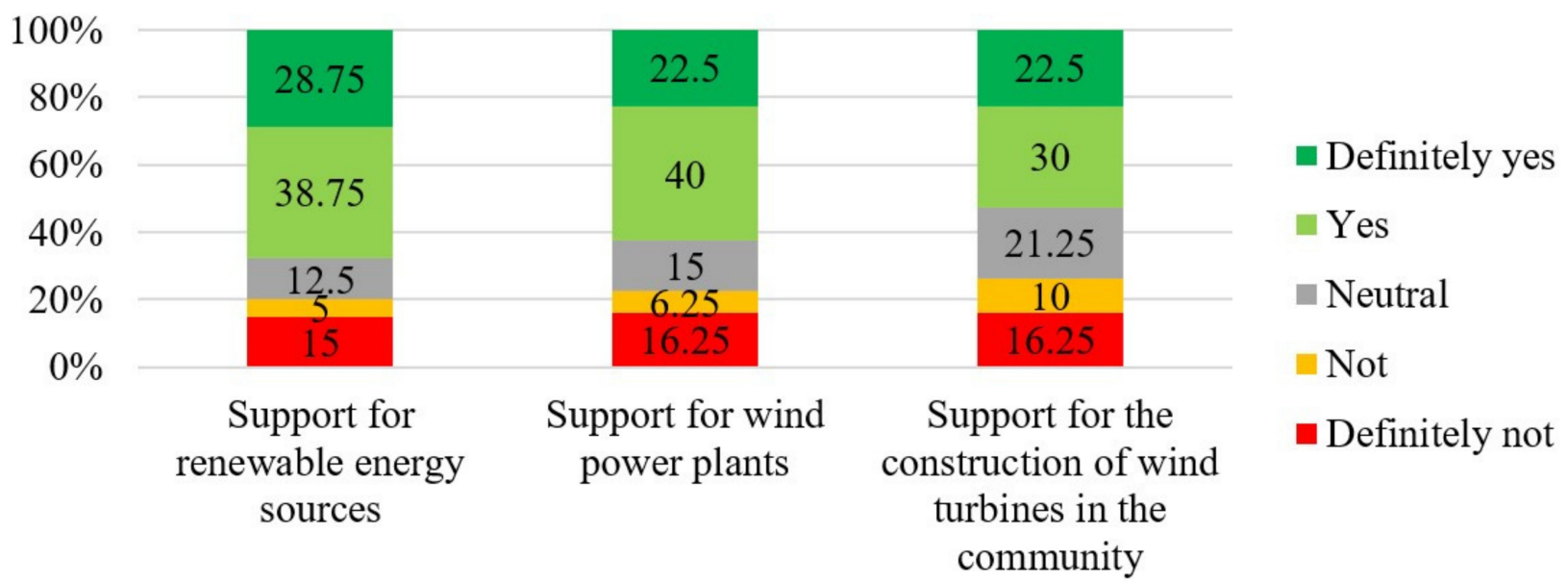

Figure 1. Support for the development of renewable energy technologies, siting of wind farms, construction of a wind farm in the municipality in which the respondents live (\%). Source: based on own research.

\subsubsection{Depending on the Demographic Characteristics of Respondents}

Women were more in favor of RETs, namely, $74 \%$ supported renewable energy technologies ( $26 \%$ strongly supported them) and only $12 \%$ were against them. A total of $59 \%$ of men declared their support (32\% strong support), but $30 \%$ opposed (19\% strongly opposed) (Figure 2). Regardless of the age brackets, supporters prevailed in every age category, with $55 \%$ of both the youngest (18-25 years old) and oldest (over 50 years of age) respondents supporting renewable energy development, compared to $3 / 4$ in favor of RET in the groups of 26-36 and 37-50-year-olds. The individuals aged 18-36 mostly declared strong support, while respondents aged over 37 years most often chose the answer "I support". The lowest support was declared by persons over 50 years old $(36 \%)$, where nearly one in three respondents opted for the answer "I strongly oppose". The support for renewable energy technologies changed in connection with the respondents' education. As many as $43 \%$ of respondents with primary education declared strong opposition. Those with vocational and secondary education declared higher support, with $43 \%$ and $84 \%$, respectively, being in favor of the development of renewable energy technologies. Two thirds of respondents with higher education declared support ( $33 \%$ chose the option "strong support"). As many as $75 \%$ of respondents whose household was composed of at least six persons did not support RET (including 50\% who strongly opposed them). This group showed no support at all. Support for RET prevailed in the other groups distinguished in terms of the size of household, but it decreased as the number of persons in one's household increased (from $80 \%$ in single-person households, through $72 \%$ in households composed of $2-3$ persons, 
to $67 \%$ when households had four to five persons). A relationship was observed between the support of renewable energy technologies and monthly disposable income per capita in a household. The least wealthy households most often expressed the lack of support (46\%). Over $3 / 4$ of persons with disposable incomes of PLN 1601-1800 per capita declared support (30\% strong support). The support for RET among the wealthiest respondents reached $70 \%$ (34\% strong support).

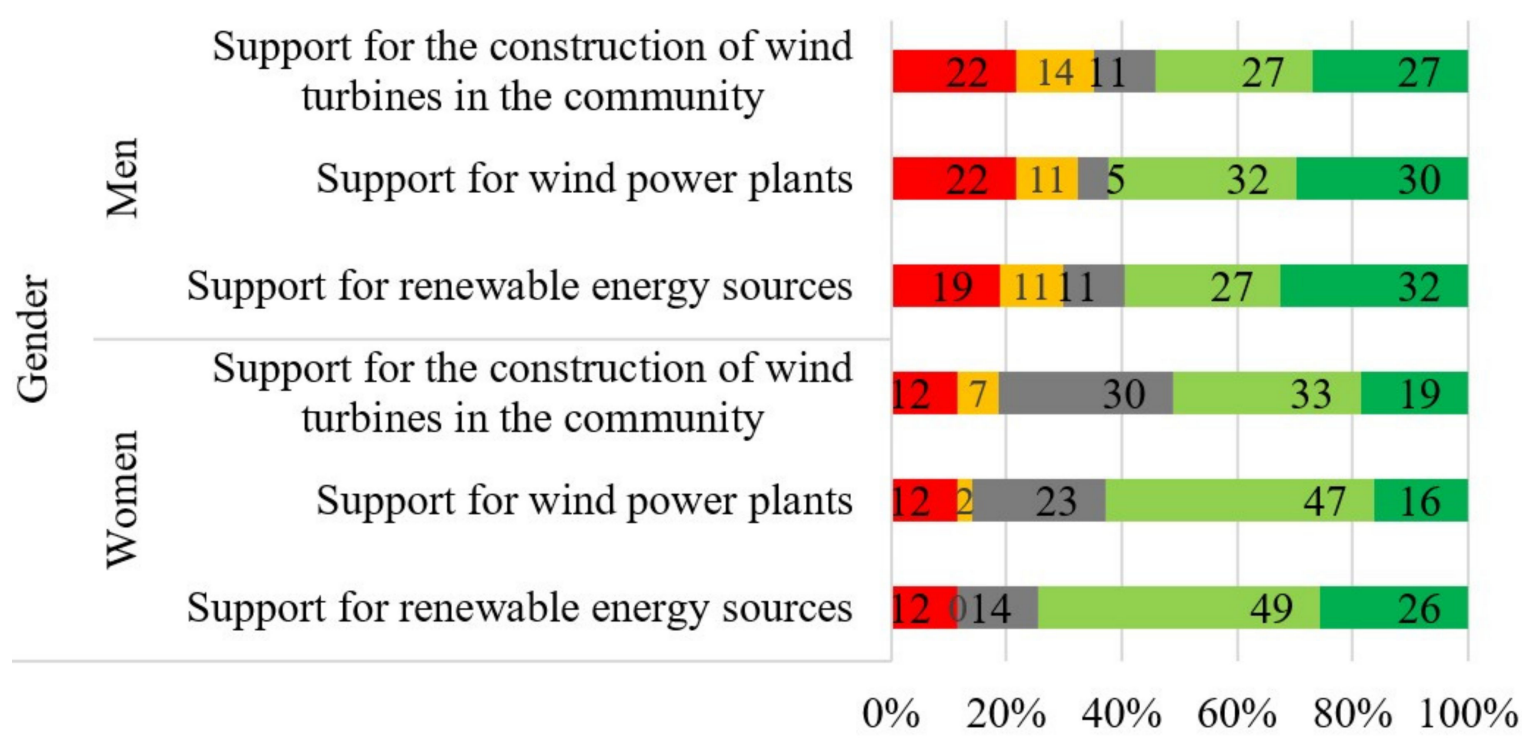

\section{घefinitely not $\quad$ Not $\quad$ Neutral $\quad$ Yes $\quad$ Definitely yes}

Figure 2. Support for the development of renewable energy technologies, siting of wind farms, construction of a wind farm in the municipality in which the respondents live according to gender of respondents (\%). Source: based on own research.

Over $60 \%$ of both men and women supported the building of wind farms, but nearly $1 / 3$ of men were against it. Nearly $1 / 4$ of women had no opinion. Irrespective of their age, the respondents supported the construction of wind farms, but the support increased with the increasing age, from $44 \%$ among the 18-25-year-old, through $71 \%$ in the group of 26-36-year-old persons, to 72\% among those aged 37-50 years, but then fell to 50\% among the oldest analyzed group. Strong support prevailed among the persons aged 26-60 years (about $28 \%$ in both age groups). The most neutral group was the youngest one (over $1 / 5$ having no opinion). The highest lack of support was declared by the youngest (33\%) and oldest $(36 \%)$ group, and the highest percentage of those who strongly opposed was among the respondents over 50 years old (32\%). Exactly the same percentage of respondents with primary or vocational education supported or did not support the development of renewable energy technologies and the siting of wind farms. Among the persons with secondary comprehensive education, the support was declared by $81 \%$ (31\% strongly support) compared to $56 \%$ (26\% strongly support) among the respondents with higher education. Nearly identical degrees of support for RETs and wind farms were declared by all respondents irrespective of the number of persons in their households or the amount of disposable income per person in a household. It was only among the wealthiest group that the general support for RETs was higher than for wind farms $(61 \%)$.

\subsection{Symptoms of the NIMBY Syndrome}

\subsubsection{Representative Research Sample}

It was found that identical percentages of respondents strongly supported and strongly opposed the development of wind farms in general and their development in the municipality of their residence $(22.5 \%$ and $16.25 \%$, respectively) (Figure 1 ). When it was specified that a wind farm would be located in the commune where the respondent lived, 
the percentage of persons who opposed it or who had no opinion about it increased at the expense of individuals who supported this development.

As many as $30 \%$ of the total population would neither support nor oppose the siting of a wind farm on an adjacent land plot. Nearly $40 \%$ of all respondents would not support such an investment (17.5\% would object to it strongly). Only $1 / 10$ of the respondents declared strong support (Figure 3).

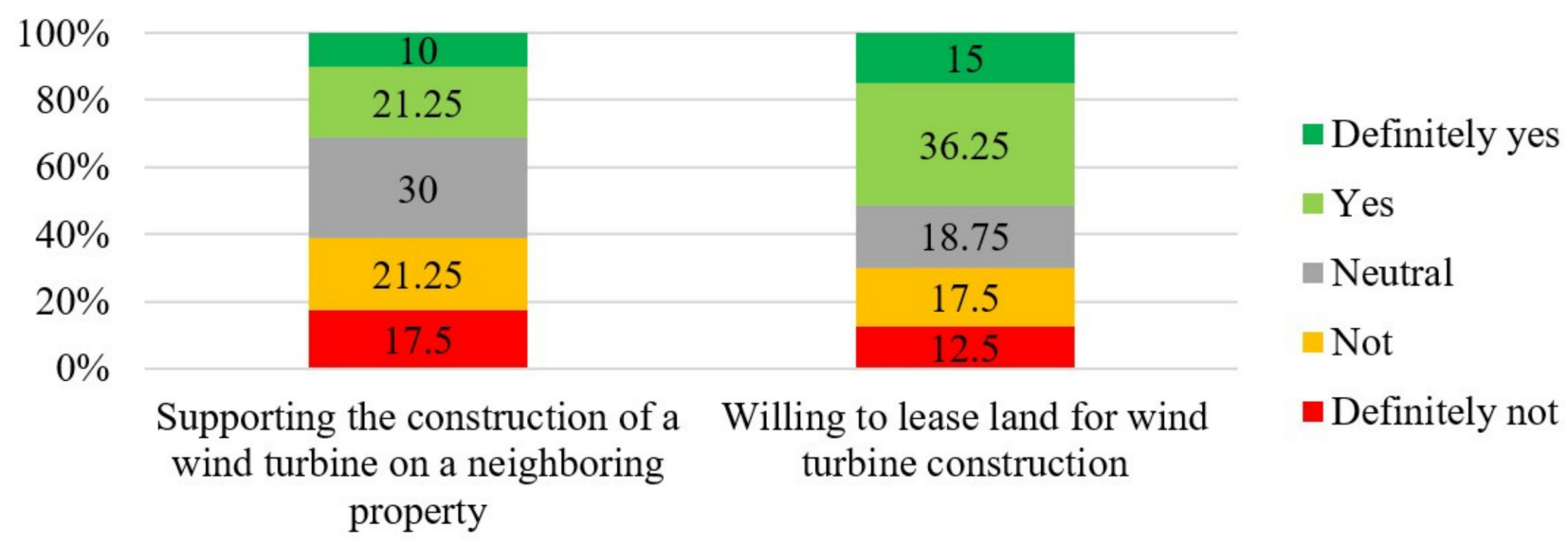

Figure 3. Support for the siting of a wind turbine on an adjacent land plot and the willingness to lease one's land for the construction of a wind turbine (\%). Source: the authors, based on own research.

Over $50 \%$ of all respondents would lease own land for the siting of a wind turbine (15\% declared strong will), and 30\% would not agree. When comparing these answers with the declared support for the building of wind farms on adjacent land plots, the percentage of those who claimed they would neither agree nor disagree is much lower. This may be a consequence of the fact that now they were asked about a land plot they owned and might prefer to manage it themselves. The percentage of those who supported the proposed solution was also higher (Figure 4). This in turn could result from the economic benefits arising from a land-lease contract. 


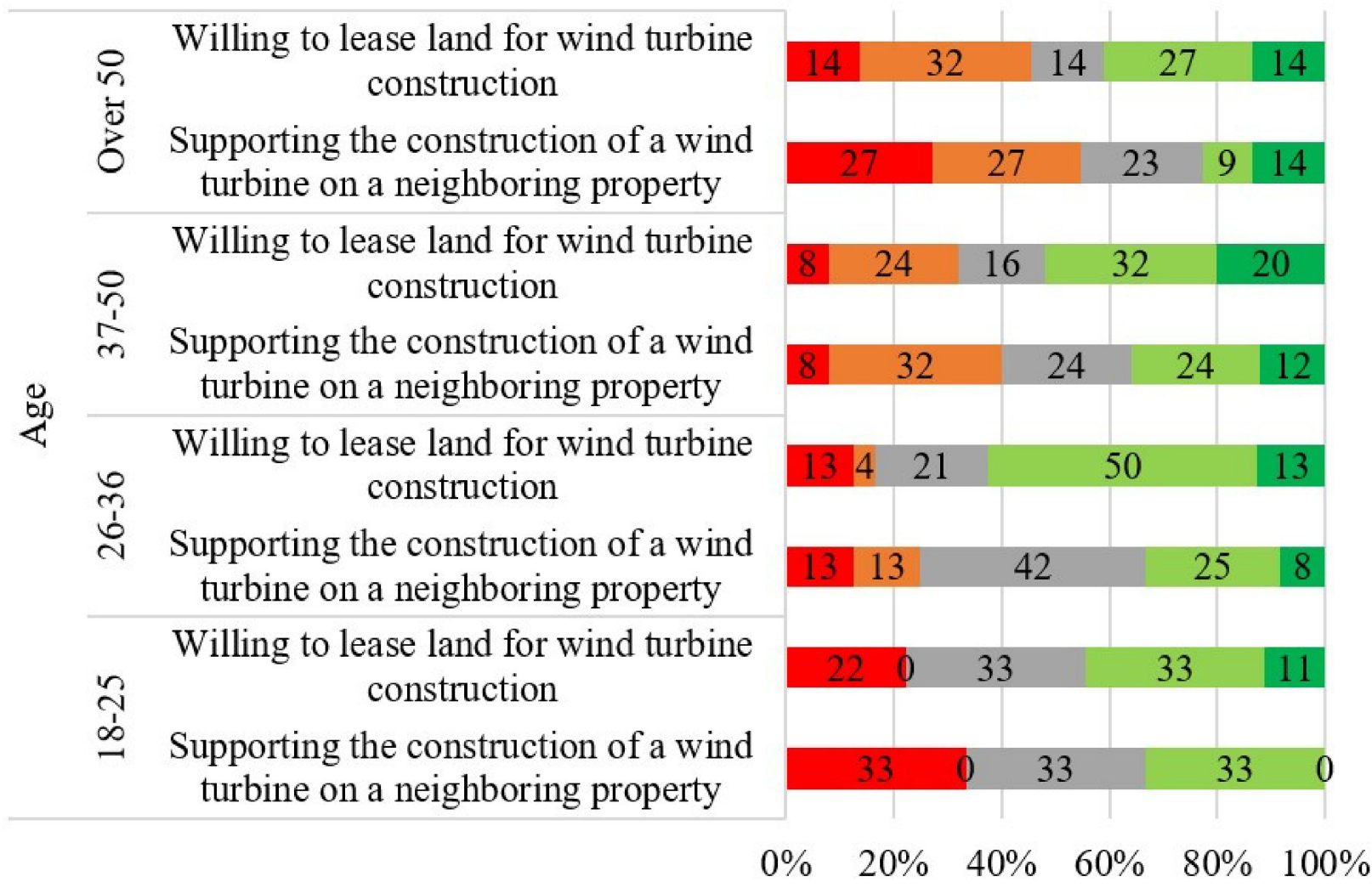

\section{- Definitely not $\quad$ Not $\backsim$ Neutral $\square$ Yes $\quad$ Definitely yes}

Figure 4. Support for the siting of a wind turbine on an adjacent land plot and the willingness to lease one's land for the construction of a wind turbine depending on the age of respondents $(\%)$. Source: based on own research.

\subsubsection{Depending on the Demographic Characteristics of Respondents}

Over $50 \%$ of both women and men supported the siting of a wind farm in the commune that was their place of residence, with $19 \%$ of women and $27 \%$ of men declaring strong support. As many as 30\% of women declared they had no opinion (compared to just $11 \%$ of men). Nearly $1 / 5$ of women and $1 / 3$ of men did not support the siting (Figure 2 ). The replies given by persons aged 18-25 years concerning the development of a wind farm anywhere and in the municipality of their residence were exactly the same. Support was indicated by $44 \%$ of respondents (11\% declared strong support), 33\% did not support it (11\% strongly opposed), and $22 \%$ had no opinion, which was the highest percentage among all age groups. The highest support (67\%) was declared by persons $26-36$ years old (1/4 expressing strong support). The support decreased with the increasing age of respondents, down to $52 \%$ among the $37-50$-year-olds and $41 \%$ among those over 50 years old. The latter group was distinguished by the highest, $41 \%$ lack of support (32\% strongly opposed). A higher percentage of persons with primary and vocational education did not support the siting of a wind farm in the municipality in which they lived (43\% and 50\%, respectively) rather than supported the development (29\% and $36 \%$, respectively). The situation was the reverse among the respondents with secondary and higher education. Support was declared by $63 \%$ and $56 \%$, respectively, while $13 \%$ and $26 \%$, respectively, opposed such an investment. A total of $3 / 4$ of persons whose household was composed of at least six persons did not support the building of a wind farm in their municipality. The highest support $(70 \%)$ was declared by persons living in one-person households. As many as $54 \%$ of the least wealthy group of respondents did not support the construction of a wind farm in the municipality of their residence. Strong support prevailed in the wealthiest group 
(32\%) with the total support climbing up to $52 \%$ of these respondents. The highest support was declared by persons with disposable income within PLN 1601-1800 (65\%).

Over $20 \%$ of women and $43 \%$ of men would support the siting of a wind turbine on an adjacent land plot (5\% of women and $16 \%$ of men would support it strongly). As many as nearly $50 \%$ of women had no opinion, compared to just $8 \%$ of men who indicated this answer. Men, rather than women, declared much less support ( $49 \%$ versus $30 \%$ ). The answers given were different depending on the age of respondents. One-third of the youngest ones would strongly oppose to it, $1 / 3$ would support it, while $1 / 3$ had no opinion about it. The next age group, 26 to 36 years old, declared greater support ( $33 \%$ and $25 \%$, respectively), but as many as $42 \%$ said they had no opinion about it. The two oldest groups were characterized by the lack of support ( $40 \%$ and $55 \%$, respectively) (Figure 2, Figure 4). As many as 57\% of persons with primary education and $38 \%$ with secondary education claimed that the siting of a wind power plant on the adjacent land plot would not matter to them. It was only among persons with secondary education that the support $(38 \%)$ exceeded the lack of it $(25 \%)$. Three-fourths of persons whose household was composed of at least six individuals did not support the construction of a wind farm on a land plot adjacent to theirs. No one in this group expressed their support. As many as $60 \%$ of persons living in single-person households and $30 \%$ of those from households composed of 4-5 persons claimed that such a development would not matter to them. The highest, $47 \%$ support, was declared by persons from households consisting of 2-3 persons. It was only in the group with disposable income between PLN 1601-1800 that a notable share expressed support for the siting of a wind turbine on an adjacent land parcel (35\%), but the same percentage declared they were neutral to such a development. As many as $62 \%$ of the less wealthy and $36 \%$ of the least wealthy respondents would not support such an investment.

Over $50 \%$ of both women and men would rent their land for the siting of a wind turbine (12\% of women and $19 \%$ of men declared they would definitely rent some land). Over $1 / 4$ of women and $1 / 3$ of men claimed they would not agree. Again, women more often showed indifference. Nearly $1 / 4$ of women said they had no opinion on this matter. As many as 30\% more respondents aged 26-36 years would rent the land they owned for the construction of a wind turbine than would support its siting on a land plot adjacent to theirs. An even more spectacular shift in the opinions was noted among interviewees aged 37-50 years, where a higher percentage would not support the siting of a wind farm on an adjacent land plot but over 50\% would rent their land for the construction of a wind turbine. The eldest respondents were more consistent-they would not support the building of a wind turbine on a neighboring land plot (55\%), nor would they lease their land for such a development (45\%), although, even here, about one in ten respondents changed their attitude. The youngest respondents were also more prone to renting their land for the siting of a wind turbine (up to $44 \%$ ) (Figure 4). It was only among respondents with primary education that the share of those who would rather not rent their land for such a development $(43 \%)$ surpassed the number of those who would agree $(29 \%)$. In the other groups, the number of those in favor exceeded those who were against, and the former increased as the level of education increased-from $50 \%$ among those with vocational schooling, through $53 \%$ among secondary-school graduates, up to $56 \%$ among respondents with university education. A total of $3 / 4$ of respondents whose households were composed of at least six persons would not lease their land for the siting of a wind turbine. No-one in this group declared their support. The respondents from households consisting of four or five persons split evenly into those who would agree to and disagree with this solution ( $43 \%$ each). In the two remaining groups of the smallest households, support prevailed, at $60 \%$ stating they would rent their land. While the less wealthy group and the one with disposable income of PLN 1601-1800 declared the lack of support for the siting of a wind turbine on an adjacent land plot or renting their own land for such a development, the wealthier respondents were observed to have different opinions-lack of support for 
building a wind farm on an adjacent land plot but willingness to rent their land plot for such a development (57\%).

\subsection{The Symptoms of the Lack of Civic Engagement}

\subsubsection{Representative Research Sample}

As many as $27.5 \%$ of the interviewees did not participate in social consultations because they did not know about them, while over $1 / 5$ did not take part in them despite having that knowledge. As many as 30\% claimed they were not interested in consultations. Just $21.5 \%$ participated in consultations, including $13.75 \%$ who made contribution to the consultations they attended (Figure 5).

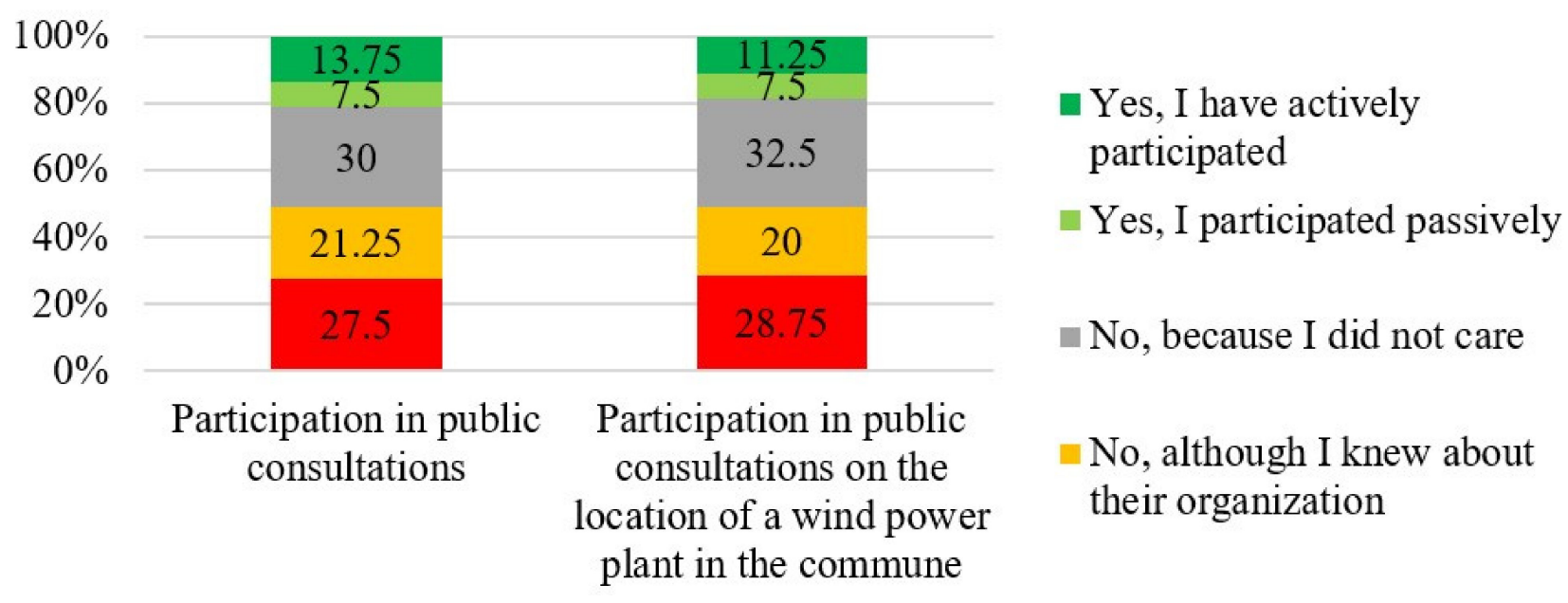

Figure 5. Participation in social consultations in general and in the case of the siting of a wind farm in the municipality of one's residence (\%). Source: based on own research.

With regards to social consultations in a municipality which is one's place of residence, the results are approximately the same. Nearly $1 / 3$ of the respondents said they were not interested in consultations, while $18.75 \%$ attended them, including $11.25 \%$ who participated in consultations actively.

Meanwhile, it is worth noting that over $31 \%$ of the respondents learnt about the siting of a wind farm in their municipality at the stage of social consultations, but-as mentioned above-only $1 / 3$ of them took part in these consultations actively, and they were mostly persons with higher education. Over $26 \%$ learnt about this fact when the construction works were well in progress. Only $7.5 \%$ found out about the development when it was completed (Figure 6).

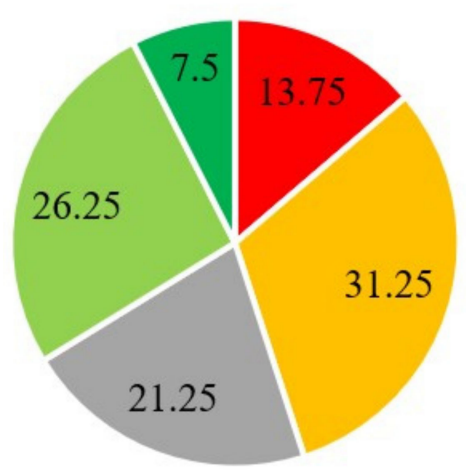

- I did not know until the start of the investment

- At the stage of public consultations

- I knew at the planning stage, but I did not care

- Advanced works were underway

- After construction was completed

Figure 6. Time when learning about the siting of a wind farm in one's municipality (\%). Source: based on own research.

One fourth of the respondents would engage in a social debate to block a wind farm in their municipality (Figure 7). 


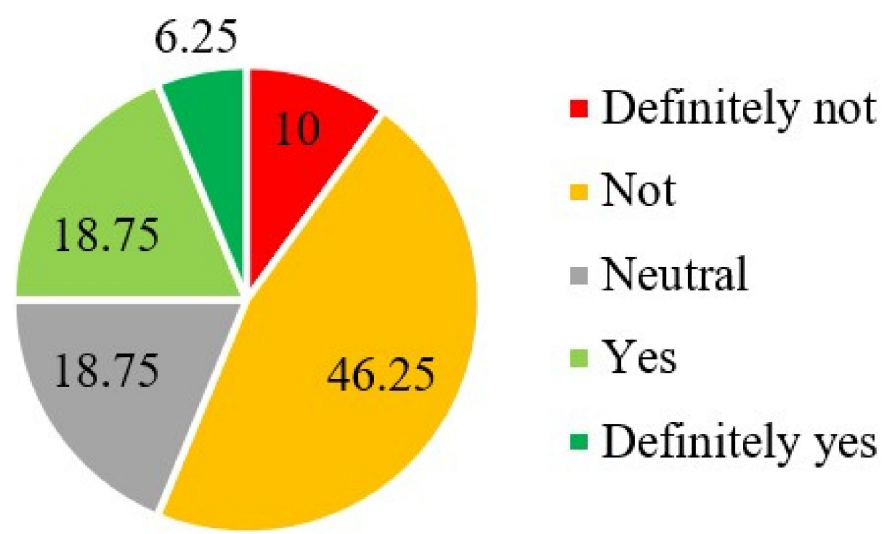

Figure 7. Willingness to participate in social debate to block the development (\%). Source: based on own research.

\subsubsection{Depending on the Demographic Characteristics of Respondents}

No distinct differences between replies emerged depending on the respondents' gender. However, more men than women partook in consultations passively $(11 \%$ and $5 \%$, respectively). No participation in consultations was the prevalent answer in every age group (from 33\% in the youngest group to 50\% among 26-36-year-olds). As many as $45 \%$ of the oldest group admitted to not knowing that such consultations were held. One third of persons aged 26-36 years did not attend consultations despite knowing they would take place, and $56 \%$ of respondents aged 18-25 years maintained that they were not interested in consultations. The highest percentage of persons who attended consultations but did not play an active role in them were in the age group of 37-50 years (12\%), while the highest percentage of active participants was in the age group of 26-36 years (25\%). No person with primary education ever participated in social consultations, and for as many as $71 \%$, this was unimportant. Much indifference to consultations was also demonstrated by persons with secondary education (44\%). The main reason why respondents with vocational and with higher education did not take part in consultation was that they were unaware of such meetings (43\% and 30\%, respectively). The distinctly highest percentage of persons who declared having actively participated in consultations were the ones with higher education $(26 \%)$. As many as $50 \%$ of persons from the most numerous households and $40 \%$ of those who lived singly did not partake in consultations because of the lack of interest. Nobody from these two groups took part in consultations, either passively or actively. The highest percentage of persons from 4-5-person households admitted to missing consultations because they did not know about them (37\%). Around 20\% of the respondents who lived in 1-3-person households took active part in consultations. The extent to which interviewees participated in social consultations varied depending on monthly disposable incomes in households per person. As many as 54\% of the least wealthy respondents never took part in consultations because they were not interested, while $8 \%$ took part in consultations actively. Over 43\% of the group with monthly incomes of PLN 1601-1800 never participated in consultations despite knowing about them, whereas $4 \%$ took active part in them. Among the wealthiest group, the most common answer was the lack of knowledge about consultations (32\%), while $1 / 5$ took part in consultations actively. Similar results were reported by Sun et al. [13], who demonstrated that delayed participation or lack thereof had negative effects on the community accepting developments that could cause social conflicts.

One third of women and $1 / 4$ of men did not take part in consultations because they did not know about them, while $14 \%$ of women and $27 \%$ of men missed consultations despite being aware of them. As many as 37\% of women and $27 \%$ of men were uninterested. A total of $7 \%$ of women participated passively and $9 \%$ actively, compared to $8 \%$ and $14 \%$ of men, respectively. Persons between 18 and 25 years of age gave nearly the same answers to the two questions. None of them participated actively in any social consultations, 
$11 \%$ admitted to passive attendance, and $56 \%$ were not interested. The only difference was the knowledge about consultations. A total of $22 \%$ never participated because they did not know such consultations were convened, while $11 \%$ missed the consultations they were aware of. As for consultations concerning the siting of a wind farm in one's home municipality, the percentages were reverse. Respondents over 50 years old were the group which most often participated in such consultations actively $(18 \%)$, while the ones aged 18-25 years most frequently admitted to passive attendance. The replies given by respondents to questions about their participation in consultations in general, or more specifically about the siting of a wind farm in their municipality, did not vary according to their education (Figure 8) or the size of their household. While the most common answers provided by interviewees with incomes below PLN 1800 to questions about their participation in social consultations generally or specifically, concerning the development of a wind farm in their municipality, were the same, the persons with the highest incomes gave a different reason why they did not participate in consultations, namely, $34 \%$ of them explained they were uninterested. Noteworthily, the wealthiest group was the only one that took active part in consultations concerning the siting of a wind farm in their municipality $(20 \%)$. The least wealthy group did not attend these consultations, not even passively.

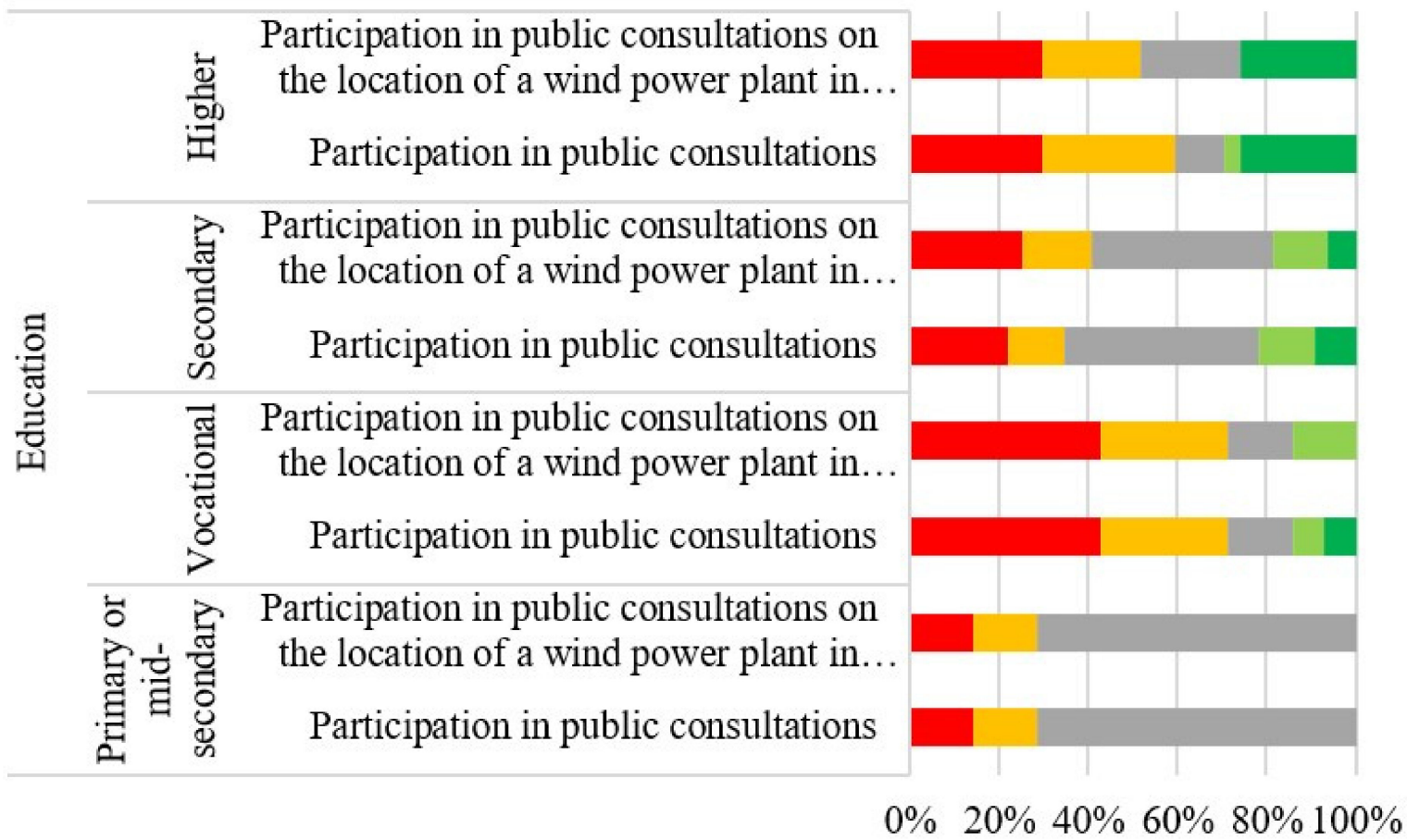

- No, because I did not know about organizing them

- No, although I knew about their organization

- No, because I did not care

-Yes, I participated passively

- Yes, I have actively participated

Figure 8. Participation in social consultations in general and in a case of the siting of a wind farm in the municipality of one's residence depending on the education of respondents (\%). Source: based on own research.

The highest percentage of women (30\%) knew about the investment at the stage of its planning but were indifferent to the plan, similar to a large percentage of young persons, aged 18-25 years (44\%), while the highest share of men (43\%) found out about the plan 
at the stage of consultations, the same as the other age groups. Depending on the level of education, the time when respondents learnt about the siting of a wind farm in their municipality differed. Over $43 \%$ of persons with primary schooling did not know about it until the investment had been launched or knew about it sooner but were indifferent to the plan. A total of $57 \%$ of persons with vocational training learnt about the project when the constructions works were well in progress. Over $1 / 3$ of persons with secondary, and nearly $50 \%$ of those with higher, education found out about the plan at the stage of consultations. Most respondents living in households with fewer than six persons found out about the siting of a wind farm in their municipality at the stage of social consultations. Persons from the most numerous households learnt about this fact when the construction was well under way, the same as the highest percentage of persons with income of less than PLN 1800. For the largest percentage within the wealthiest group (41\%), being the only one that actively participated in social consultations, these meetings provided an opportunity to learn about the plan to develop a wind power plant in their municipality.

The smallest and largest households most often chose the actual distance within $2.1-3 \mathrm{~km}(40 \%$ and $50 \%$, respectively). The other groups indicated the distance $3.1-5 \mathrm{~km}$ ( $31 \%$ and $33 \%$, respectively). It was only the respondents from the households with two to three persons that most often claimed that the actual distance was also the most satisfactory one (36\%). As for the other groups, the most frequent distance indicated was $5 \mathrm{~km}: 60 \%$ in single-person households, $50 \%$ each for household with 4-5 persons and households with more than six persons. When asked about satisfactory distance, respondents gave varied answers, but often indicated a distance similar to the actual one (Figure 9).

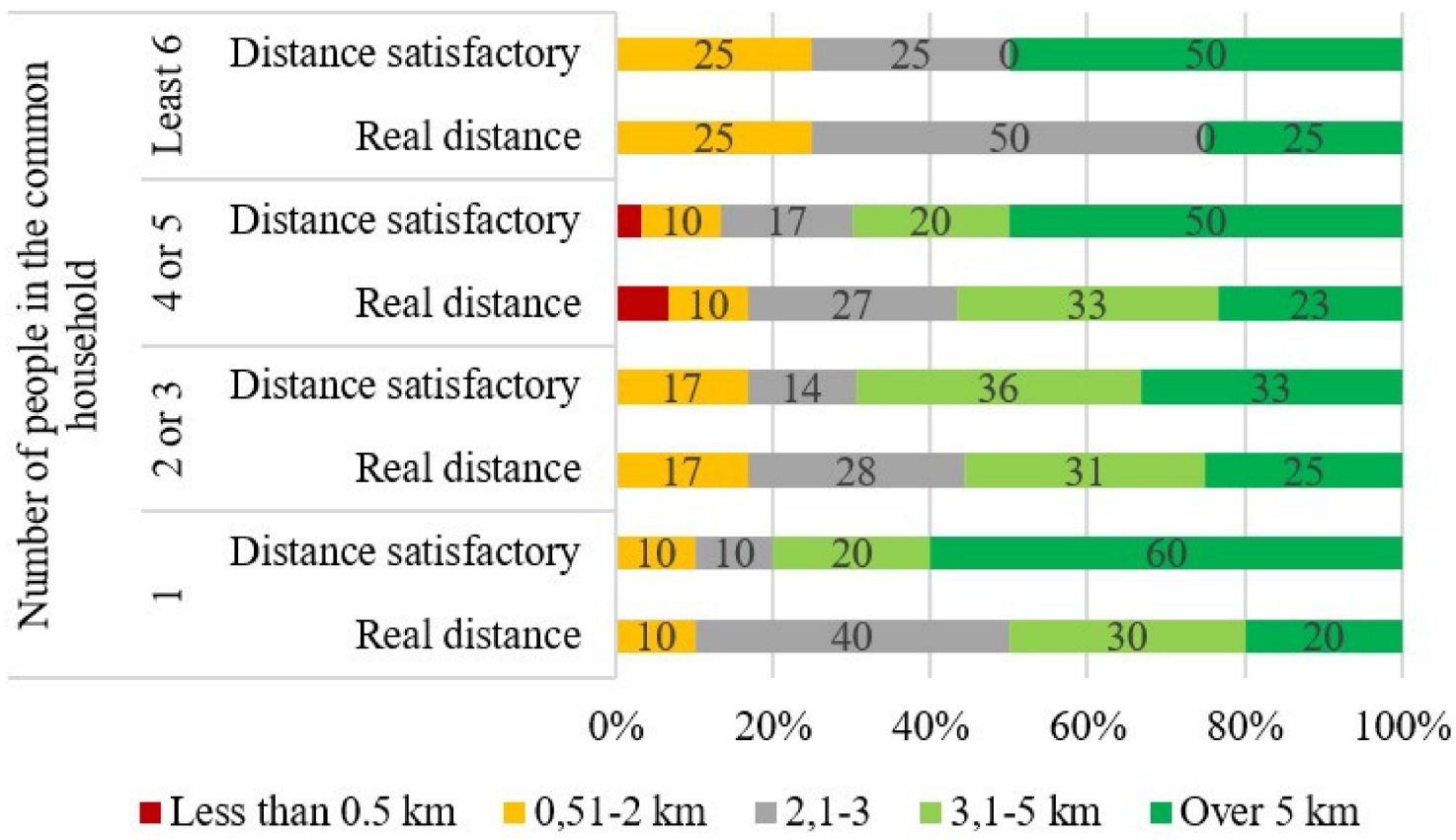

Figure 9. The indication of a satisfactory distance of the wind farm from buildings depending on the number of people in the household (\%). Source: based on own research.

Over $62 \%$ of the respondents from the least wealthy group chose the actual distance as within the range of $3.1-5 \mathrm{~km}(31 \%$ chose $2.1-3 \mathrm{~km}$, the same as $3.1-5 \mathrm{~km})$. A total of $35 \%$ each from the group with the income of PLN 1601-1800 opted for the distances of 2.1-3 km and over $5 \mathrm{~km}$. The group with the income between PLN 1601-1800 decided that the satisfactory distance would be over $3.1 \mathrm{~km}$ (43\% each). The other groups declared that a distance over $5 \mathrm{~km}$ (54\% of the least wealthy and $41 \%$ of the wealthiest) would be acceptable.

Twenty-one percent of all women and 30\% of men who took part in our study would engage in a social debate to block a wind farm in their municipality. None of the respon- 
dents marked the reply "does not apply" intended as an option for those who knew about the development and engaged in social debate to obstruct it. Nearly $1 / 5$ of respondents did not have an opinion about it. Over $56 \%$ did not express a wish to possibly engage ( $60 \%$ of women and $51 \%$ of men). It was only the youngest respondents, aged $18-25$ years, that would engage in social debate to block the development if they knew about it (44\%). The other age groups were mostly unwilling to become involved, and the degree of their willingness to participate in social debate decreased with increasing age: from $71 \%$ in the $26-36$-yearold group, through $56 \%$ among $37-50$-year-olds, to $50 \%$ among persons over 50 years old. Nearly $1 / 4$ of the respondents aged $37-50$ years did not have an opinion in this matter. Equal percentages $(43 \%$ each) of persons with primary education declared possible willingness or unwillingness to participate in social debate to prevent the construction of a wind power plant. Among the respondents with vocational education, the willingness to participate in such social debates prevailed (43\%), and no-one in this group declared themselves as definitely willing or unwilling to engage in such debate. Persons with secondary and higher education expressed the lack of will (59\% and 70\%, respectively).

Respondents from households with fewer than six persons most often declared they were unwilling to take part in social debate to block the development, but the percentage of such replies decreased as the number of persons in a household increased: from $80 \%$ in single-person households, through $67 \%$ in $2-3$-person households, to $43 \%$ in households with four and five persons. In the largest households, with at least six persons, $1 / 2$ of respondents declared the lack of willingness. Most persons with incomes over PLN 1601 would not engage in social debate aiming to block the development $(65 \%$ and $57 \%$, respectively). A total of $38 \%$ each from the least wealthy group declared either the willingness or unwillingness to take part in such debate (Figure 10). The oldest persons were more consistent and would not support the siting of a wind turbine on an adjacent land plot, which was particularly manifested among persons with the lower social status. In this study, this group was defined as persons with the lowest education and earnings.

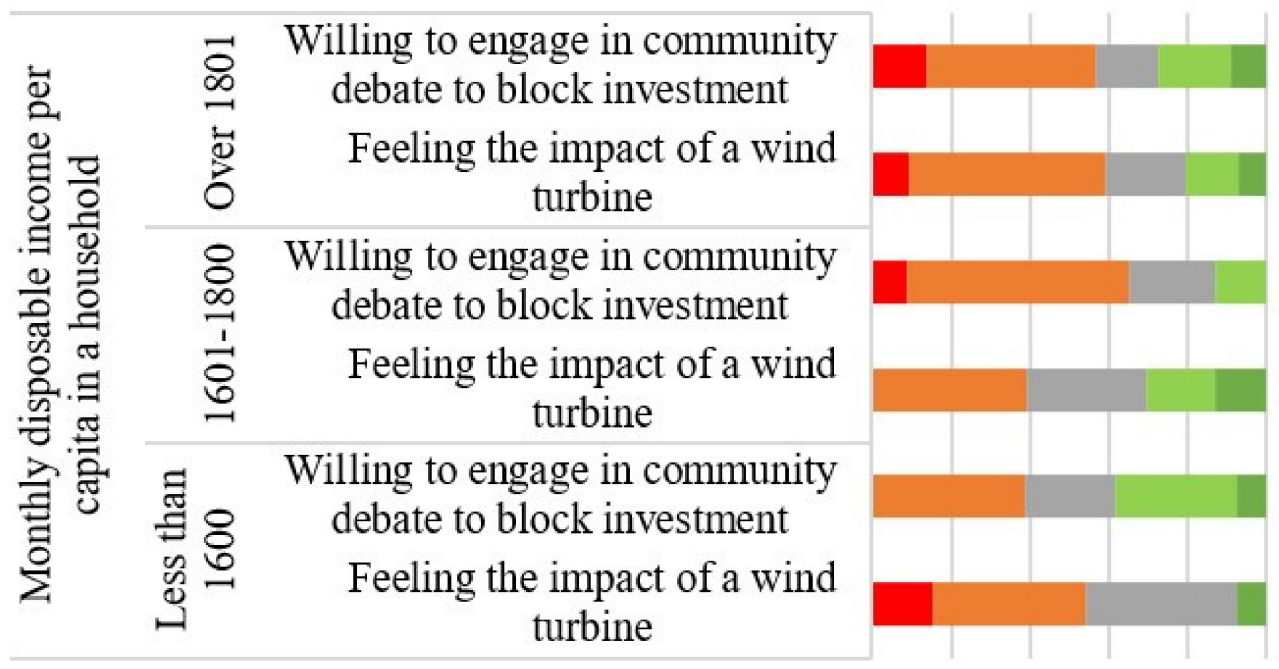

$0 \% 20 \% 40 \% 60 \% 80 \% 100 \%$

\section{-Definitely not $\quad$ Not Neutral $\square$ Yes $\quad$ Definitely yes}

Figure 10. Willingness to participate in social debate to block the development depending on the monthly disposable income per capita in a household (\%). Source: based on own research.

Differences in the support for the siting of a wind turbine on an adjacent land parcel and the willingness to lease one's land for such a development are interesting to notice. The idea of renting a land plot was met with less indifference. Possible reasons could be the wish to have complete control over one's land as an object of ownership and, 
on the other hand, the prospect of economic benefits from leasing land. Only persons aged 50 years and over consistently expressed the lack of support to the development of a wind farm on either an adjacent land plot or on one's own land. The other age groups were more favorable to the concept of building a wind farm on one's land. This may implicate the higher sense of NIMBYism among the oldest respondents than among the other groups. A change in the attitude was observed among the wealthiest respondents-whereas they were reluctant to accept the siting of a wind turbine on an adjacent land plot, they would support the development if it was planned on their land parcel.

The situation is different among the youngest respondents. No-one in this age group participated actively in social consultations, $11 \%$ attended them only passively, and 56\% were not interested. It needs to be added that over $31 \%$ of respondents found out about the siting of a wind farm in a municipality in which they live at the stage of social consultations, but-as mentioned before-slightly over $1 / 3$ took part in consultations, and these were mostly persons with a higher social status, i.e., with higher education and highest incomes. Individuals with primary education and with lowest incomes least often participated in social consultation.

\section{Conclusions}

The vast majority of respondents expressed support for both renewable energy sources and wind turbine construction. The support for renewable energy sources definitely decreased with the increase of the number of people in the respondents' households. A similar tendency was observed when analyzing attitudes towards the RET depending on the income of respondents-support was lowest in households with the lowest income per capita. The support for the construction of wind power plants increased with the age of respondents.

As the respondents indicated the location of a wind power plant in their municipality of residence, the support for this type of investment decreased. Thus, the NIMBY syndrome was observed. The support decreased with the age of the respondents. Similarly, the lower the level of education, the more the lack of support outweighed support, and the lower the income, the lower the support.

A higher percentage of respondents said they would lease their land for the location of a wind turbine than would support locating it on a neighboring property. This may be due to the economic benefits of the land-lease agreement. Respondents from the most numerous households expressed a complete lack of support for building a wind power plant on a neighboring property. Only the oldest group of respondents declared both a lack of support for the construction of a wind power plant on a neighboring property and a willingness to lease their own property for such an investment. People from the most numerous households declared a complete lack of interest in leasing their land.

The most common reason for not participating in social consultations in general and in consultations on wind farm location in the municipality where the respondents live in particular was the lack of interest in them. Thus, there is a lack of civic engagement. The highest percentage of people actively participating in public consultations ever were people aged 26-36 with higher education. No person with primary education has ever participated in social consultations.

Despite declarations of the lack of knowledge about public consultations by nearly $29 \%$ of respondents, as many as $31 \%$ of them learned about the location of a wind power plant in a municipality at the consultation stage. This mainly concerned people with higher education.

Most respondents did not want to participate in a social debate in order to block the investment. Both the young and the least affluent did not express a desire to participate in the social debate.

The survey proved that both the NIMBY syndrome and a lack of civic engagement shape the attitudes towards renewable energy technologies in rural areas. However, certain tendencies can be observed towards more pronounced attitudes depending on 
socioeconomic conditions. The hypothesis set in the study was confirmed, namely, that socioeconomic factors shape attitudes towards renewable energy. The research results implicated that the measures taken to promote renewable energy technologies should be designed differently depending on the socioeconomic situation of the targeted audience. Young people might be reached via social media, appropriately to their age, and through campaigns promoting local investments. For older persons, traditional ways of communication can be used, but the information transmitted should include specific benefits for the whole society as well as for individual households. This is confirmed by research results of other scholars, to whom references were made in the literature review $[53,96]$.

Although the results of the study concern a small research sample, rural areas in Poland are characterized by a certain specificity of inhabitants' behaviors, which entitles to draw conclusions and to make generalizations related to broader groups of population. While conducting the research, the authors encountered difficulties in reaching inhabitants willing to participate in the research.

Numerous global and international, as well as national, legal acts and institutions point out the necessity of using renewable energy sources. A sustainable energy future is based on renewable energy sources. The use of fossil fuels should be abandoned. An alternative can be found, among others, in wind energy. Therefore, it is important to analyze the attitudes of local communities towards the development of wind energy. Numerous studies show that investments in renewable energy sources, in general, and wind farms, in particular, may cause protests of local communities. They may be caused by the NIMBY syndrome described in the article. On the other hand, lack of civic engagement also affects attitudes towards renewable energy sources.

The need to scale up the use of renewable energy sources, including wind energy, will probably contribute to the evolution of local communities' attitudes towards them. It is hoped that in the long run, both through the introduction of innovative technologies and through changes in the mentality of the local community, civic participation will increase and the NIMBY ("not in my backyard") syndrome will be replaced by its opposite, YIMBY ("yes in my backyard").

Author Contributions: Conceptualization, M.W.-D. and N.Ś.; methodology, M.W.-D., N.Ś., and A.N.B.; software, N.Ś.; validation, M.W.-D., N.Ś., and A.N.-B.; formal analysis, M.W.-D., N.Ś., and A.N.-B.; investigation, M.W.-D. and N.Ś.; resources, A.N.-B.; data curation, N.Ś.; writing-original draft preparation M.W.-D., N.Ś., and A.N.-B.; writing-review and editing; visualization, M.W.-D., N.Ś., and A.N.-B.; supervision, M.W.-D. and N.Ś.; funding acquisition, M.W.-D., N.Ś., and A.N.-B. All authors have read and agreed to the published version of the manuscript.

Funding: This research received no external funding.

Institutional Review Board Statement: Not applicable.

Informed Consent Statement: Not applicable.

Data Availability Statement: Data available from the authors.

Conflicts of Interest: The authors declare no conflict of interest.

\section{References}

1. International Renewable Energy Agency, "IRENA". 2019. Available online: https:/ /www.irena.org (accessed on 31 August 2021).

2. Energia ze Źródeł Odnawialnych. Available online: https://www.europarl.europa.eu/factsheets/pl/sheet/70/energia-zezrodel-odnawialnych (accessed on 8 November 2021).

3. Act on Renewable Energy Resources, 20 February 2015, Dz. U. of 2021, item 610. Available online: http://isap.sejm.gov.pl/ isap.nsf/DocDetails.xsp?id=WDU20150000478\&SessionID=B0F0E9DBB04CE47C3EC8BF5FFD73491E265292BB (accessed on 8 November 2021).

4. Act on Wind Farm Investments, 20 May 2016, Dz. U. of 2021, item 724. Available online: https://isap.sejm.gov.pl/isap.nsf/ DocDetails.xsp?id=WDU20160000961 (accessed on 8 November 2021).

5. Weber, A. Über den Standort der Industrien; Mohr Siebeck Verlag: Heidelberg, Germany, 1922; p. 264.

6. Brodziński, Z.; Brodzińska, K.; Szadziun, M. Photovoltaic Farms-Economic Efficiency of Investments in North-East Poland. Energies 2021, 14, 2087. [CrossRef] 
7. Pred, A. Behaviour and Location: Foundations for a Geographic and Dynamic Location Theory; The Royal University of Lund, Department of Geography Studies in Geography: Lund, Sweden, 1967; p. 280.

8. Pilewicz, T.; Sabat, W. Behavioural location theory-Evolution, tools and future. Kwart. Nauk. Przedsiębiorstwie 2018, 46, 61-68. [CrossRef]

9. Hektus, P. Czynniki Lokalizacji Elektrowni Wiatrowych W Polsce. Ph.D. Thesis, Wydział Geografii Społeczno-Ekonomicznej i Gospodarki Przestrzennej, Poznań, Poland, 2020; pp. 35-58.

10. Pindór, T.; Preisner, L. Wykorzystanie Wybranych Odnawialnych Źródet Energii w Kontekście Kryteriów Rozwoju Zrównoważonego; Prace Naukowe Uniwersytetu Ekonomicznego we Wrocławiu: Wrocław, Poland, 2011; pp. 186-196.

11. Bielski, S.; Marks-Bielska, R.; Zielińska-Chmielewska, A.; Romaneckas, K.; Šarauskis, E. Importance of Agriculture in Creating Energy Security-A Case Study of Poland. Energies 2021, 14, 2465. [CrossRef]

12. Włodarczyk, B.; Firoiu, D.; Ionescu, G.; Ghiocel, F.; Szturo, M.; Markowski, L. Assessing the Sustainable Development and Renewable Energy Sources Relationship in EU Countries. Energies 2021, 14, 2323. [CrossRef]

13. Bednarek-Szczepańska, M.; Dmochowska-Dudek, K. Syndrom NIMBY jako wyzwanie dla jednostek samorządu. Maz. Stud. Reg. 2017, 21, 103-114. [CrossRef]

14. Wolsink, M. Wind power and the NIMBY-myth: Institutional capacity and the limited significance of public support. Renew. Energy 2000, 21, 49-64. [CrossRef]

15. Sun, L.; Zhua, D.; Chan, E.H.W. Public Participation Impact on Environment NIMBY Conflict and Environmental Conflict Management: Comparative Analysis in Shanghai and Hong Kong. Land Use Policy 2016, 58, 208-217. [CrossRef]

16. Tropman, J.E.; O’Hare, M.; Bacow, L.; Sanderson, D. Facility Siting and Public Opposition. J. Policy Anal. Manag. 1985, 4, 626. [CrossRef]

17. Bukraba-Rylska, I. Kultura w Społeczności Lokalnej-Podmiotowość Odzyskana? IRWiR PAN: Warszawa, Poland, $2000 ;$ p. 11.

18. Kłoczko-Gajewska, A. Aktywność obywatelska na wsi-Studium przypadku czterech wsi na Podlasiu. Zeszyty Naukowe Szkoły Głównej Gospodarstwa Wiejskiego. Ekon. Organ. Gospod. Żywnościowej 2006, 59, 121-137.

19. Filipowicz, M.; Żołąek, M.; Ochalik, J. Growth Potential and Problems in Development of Wind Energy; Rynek Instalacyjny: Warszawa, Poland, 2020.

20. Stan Energetyki Wiatrowej w Polsce w 2016 Roku; Polskie Stowarzyszenie Energetyki Wiatrowej: Szczecin, Poland, 2017.

21. New Energy Outlook. Bloomberg New Energy Finance; Bloomberg Finance L.P.: New York, NY, USA, 2016.

22. Cortés, E.; Sánchez, F.; O’Carroll, A.; Madramany, B.; Hardiman, M.; Young, T.M. On the Material Characterisation of Wind Turbine Blade Coatings: The Effect of Interphase Coating-Laminate Adhesion on Rain Erosion Performance. Materials 2017, 10, 1146. [CrossRef]

23. Renewables 2016: Global Status Report (GSR), 2017, 118-131. Available online: http:/ / www.ren21.net/.ShowinContext (accessed on 8 November 2021).

24. Global Wind Statistics 2016. 2017. Available online: www.gwec.net (accessed on 8 November 2021).

25. Ehrenhald, W. Założenia do Strategii Rozwoju Energetyki Wiatrowej w Polsce. Available online: https://zpp.net.pl/wp-content/ uploads /2019/04/Za\%C5\%82o\%C5\%BCenia-do-strategii-rozwoju-energetyki-w-Polsce-wersja-elektroniczna.pdf (accessed on 8 November 2021).

26. World Adds Record New Renewable Energy Capacity in 2020. Available online: https://www.irena.org/newsroom/ pressreleases/2021/Apr/World-Adds-Record-New-Renewable-Energy-Capacity-in-2020 (accessed on 8 November 2021).

27. Liserre, M.; Cardenas, R.; Molinas, M.; Rodriguez, J. Overview of multi-MW wind turbines and wind parks. IEEE Trans. Ind. Electron. 2011, 58, 1081-1095. [CrossRef]

28. Chen, Z.; Guerrero, J.M.; Blaabjerg, F. A review of the state of the art of power electronics for wind turbines. IEEE Trans. Power Electron. 2009, 24, 1859-1875. [CrossRef]

29. Blaabjerg, F.; Chen, F.; Kjaer, S.B. Power electronics as efficient interface in dispersed power generation systems. IEEE Trans. Power Electron. 2004, 19, 1184-1194. [CrossRef]

30. Blaabjerg, F.; Liserre, M.; Ma, K. Power electronics converters for wind turbine systems. IEEE Trans. Ind. Appl. 2012, 48, 708-719. [CrossRef]

31. Blaabjerg, F.; Ma, K. Future on power electronics for wind turbine systems. IEEE J. Emerg. Sel. Topics Power Electron. 2013, 1, 139-152. [CrossRef]

32. Hansen, A.D.; Iov, F.; Blaabjerg, F.; Hansen, L.H. Review of contemporary wind turbine concepts and their market penetration. J. Wind Eng. 2004, 28, 247-263. [CrossRef]

33. Control in Power Electronics: Selected Problems; Academic: San Diego, CA, USA, 2002.

34. Morris, C. Denmark surpasses 100 percent wind power-Energy Transition. Available online: https://energytransition.org/2013 /11/denmark-surpasses-100-percent-wind-power/ (accessed on 8 November 2021).

35. Website of MHI Vestas Offshore Wind. 2017. Available online: http:/ / www.mhivestasoffshore.com/ (accessed on 8 November 2021).

36. Margonelli, L. Clean Energy's Dirty Little Secret the Atlantic, May 2009. Available online: /http://www.theatlantic.com/doc/20 0905/hybrid-cars-mineralsS (accessed on 8 November 2021).

37. Hurst, C. China's Rare Earth Elements Industry: What Can the West Learn? Institute for the Analysis of Global Security: Washington, DC, USA, 2010. Available online: http://fmso.leavenworth.army.mil/documents/rareearth.pdfS (accessed on 8 November 2021). 
38. Enevoldsen, P.; Permien, F.-H.; Bakhtaoui, I.; von Krauland, A.-K.; Jacobson, M.Z.; Xydis, G.; Sovacool, B.K.; Valentine, S.V.; Luecht, D.; Oxley, G. How much wind power potential does europe have? Examining european wind power potential with an enhanced socio-technical atlas. Energy Policy 2019, 132, 1092-1100. [CrossRef]

39. Marvel, K.; Kravitz, B.; Caldeira, K. Geophysical limits to global wind power. Nat. Clim. Change 2012, 3, 118-121. [CrossRef]

40. Arnqvist, J. Mean Wind and Turbulence Conditions in the Boundary Layer Above Forests Acta Universitatis Upsaliensis, Uppsala. 2015. Available online: http:/ / urn.kb.se/resolve?urn=urn:nbn:se:uu:diva-237764 (accessed on 8 November 2021).

41. Valentine, S.V. Wind Power Politics and Policy; Oxford University Press: Oxford, UK, 2014.

42. Lorenc, H. Struktura i Zasoby Energetyczne Wiatru w Polsce; ImiGW: Warszawa, Poland, 1996; Available online: http://www. rynekinstalacyjny.pl/artykul/id4944, potencjal-rozwoju-i-problemy-energetyki-wiatrowej (accessed on 8 November 2021).

43. Scally, C.P.; Tighe, J.R. Democracy in Action? NIMBY as Impediment to Equitable Affordable Housing Siting. Hous. Stud. 2015, 30, 749-769. [CrossRef]

44. McClymont, K.; O'Hare, P. We're not NIMBYs! Contrasting local protest groups with idealised conceptions of sustainable communities. Local Environ. 2008, 13, 321-335. [CrossRef]

45. Owens, S. Engaging the Public: Information and Deliberation in Environmental Policy. Environ. Plan. A Econ. Space 2000, 32, 1141-1148. [CrossRef]

46. Eranti, V. Re-visiting NIMBY: From conflicting interests to conflicting valuations. Sociol. Rev. 2016, 65, 285-301. [CrossRef]

47. Burningham, K. Using the Language of NIMBY: A topic for research, not an activity for researchers. Local Environ. 2000, 5, 55-67. [CrossRef]

48. Petrova, M.A. From NIMBY to acceptance: Toward a novel framework-VESPA-For organizing and interpreting community concerns. Renew. Energy 2016, 86, 1280-1294. [CrossRef]

49. Ratnasingham, S.; Hebert, P.D. BOLD: The Barcode of Life Data System. Mol. Ecol. Notes 2007, 7, 355-364. [CrossRef]

50. Wassmer, R.W.; Wahid, I. Does the Likely Demographics of Affordable Housing Justify NIMBYism? Hous. Policy Debate 2018, 29, 343-358. [CrossRef]

51. Bell, D.; Gray, T.; Haggett, C. The Social Gap in Wind Farm Siting Decisions: Explanations and Policy Responses. Environ. Polit. 2005, 14, 460-477. [CrossRef]

52. Van der Horst, D. NIMBY or not? Exploring the relevance of location and the politics of voiced opinions in renewable energy siting controversies. Energy Policy 2007, 35, 2705-2714. [CrossRef]

53. Bednarek-Szczepańska, M.; Dmochowska-Dudek, K. Syndrom NIMBY na obszarach wiejskich w Polsce: Uwarunkowania i Specyfika Konfliktów Wokót Lokalizacji Niechcianych Inwestycji; Prace Geograficzne/Polska Akademia Nauk, Instytut Geografii i Przestrzennego Zagospodarowania im. Stanisława Leszczyckiego: Warszwa, Poland, 2016; Available online: https://www.rcin.org.pl/ dlibra/publication/83071/edition/ 63425 (accessed on 8 November 2021).

54. Mann, S.; Kögl, H. On the acceptance of animal production in rural communities. Land Use Policy 2003, 20, 243-252. [CrossRef]

55. Martin, R. Community Perceptions About Prison Construction: Why Not in My Backyard? Prison J. 2000, 80, 265-294. [CrossRef]

56. Rahardyan, B.; Matsuto, T.; Kakuta, Y.; Tanaka, N. Resident's concerns and attitudes towards Solid Waste Management facilities. Waste Manag. 2004, 24, 437-451. [CrossRef] [PubMed]

57. Caplan, A.; Grijalva, T.; Jackson-Smith, D. Using choice question formats to determine compensable values: The case of a landfill-siting process. Ecol. Econ. 2007, 60, 834-846. [CrossRef]

58. Upreti, B.R. Conflict over biomass energy development in the United Kingdom: Some observations and lessons from England and Wales. Energy Policy 2004, 32, 785-800. [CrossRef]

59. Schumacher, K.; Schultmann, F. Local Acceptance of Biogas Plants: A Comparative Study in the Trinational Upper Rhine Region. Waste Biomass Valorization 2017, 8, 2393-2412. [CrossRef]

60. Takahashi, L.M.; Dear, M.J. The Changing Dynamics of Community Opposition to Human Service Facilities. J. Am. Plan. Assoc. 1997, 63, 79-93. [CrossRef]

61. Evans, K. It Takes a Tiny House Village: A Comparative Case Study of Barriers and Strategies for the Integration of Tiny House Villages for Homeless Persons in Missouri. J. Plan. Educ. Res. 2021. [CrossRef]

62. O'Neil, S.G. Community obstacles to large scale solar: NIMBY and renewables. J. Environ. Stud. Sci. 2020, 11, 85-92. [CrossRef]

63. Jarvis, S. The Economic Costs of NIMBYism-Evidence from Renewable Energy Projects; No. crctr224_2021_300; University of Bonn and University of Mannheim: Mannheim, Germany, 2021.

64. Uji, A.; Prakash, A.; Song, J. Does the "NIMBY syndrome" undermine public support for nuclear power in Japan? Energy Policy 2020, 148, 111944. [CrossRef]

65. Aldrich, D.P. Site Fights; Cornell University Press: Ithaca, NY, USA, 2011. [CrossRef]

66. Lesbirel, H. NIMBY Politics in Japan; Cornell University Press: Ithaca, NY, USA, 2019.

67. Okuda, I.; Thomson, V.E. Regionalization of Municipal Solid Waste Management in Japan: Balancing the Proximity Principle with Economic Efficiency. Environ. Manag. 2007, 40, 12-19. [CrossRef]

68. Lucki, Z.; Misiak, W. Energetyka a Społeczeństwo: Aspekty Socjologiczne; Wydawnictwo Naukowe PWN: Warszawa, Poland, 2010.

69. Wolsink, M. Social acceptance revisited: Gaps, questionable trends, and an auspicious perspective. Energy Res. Soc. Sci. 2018, 46, 287-295. [CrossRef]

70. McAvoy, G.E. Partisan Probing and Democratic Decisionmaking Rethinking the Nimby Syndrome. Policy Stud. J. 1998, 26, 274-292. [CrossRef] 
71. Hunter, S.; Leyden, K.M. Beyond NIMBY. Explaining Opposition to Hazardous Waste Facilities. Policy Stud. J. 1995, $23,601-619$. [CrossRef]

72. Devine-Wright, P. Rethinking NIMBYism: The role of place attachment and place identity in explaining place-protective action. J. Community Appl. Soc. Psychol. 2009, 19, 426-441. [CrossRef]

73. Mocavini, G. The Trans-Adriatic Pipeline and the Nimby Syndrome. Roma Tre Law Rev. 2019, 1, 178-189.

74. He, L.; Yang, Q.; Liu, X.; Fu, L.; Wang, J. Exploring Factors Influencing Scenarios Evolution of Waste NIMBY Crisis: Analysis of Typical Cases in China. Int. J. Environ. Res. Public Health 2021, 18, 2006. [CrossRef]

75. Yu, B.; Han, Y.H.; Sun, Y.; Zhang, X.D. The community residents' NIMBY attitude on the construction of com-munity ageing care service centres: A cross-sectional study. BMC Health 2021. [CrossRef]

76. Keeley, A.R.; Komatsubara, K.; Managi, S. The value of invisibility: Factors affecting social acceptance of renewable energy. Energy Sources Part B Econ. Plan. Policy 2021, 1-20. [CrossRef]

77. Rountree, V.; Baldwin, E.; Hanlon, J. A review of stakeholder participation studies in renewable electricity and water: Does the resource context matter? J. Environ. Stud. Sci. 2021, 1-16. [CrossRef]

78. Arbel, Y.; Arbel, Y.; Kerner, A.; Kerner, M. To lockdown or not against COVID19: Can the power of education provide the answer? Cities 2021, 103477, in press. [CrossRef]

79. He, S. Nimby Behavior in Epidemic Prevention and Control and Its Governance from the Rule of Law. J. Hum. Rts. 2020, 19, 192.

80. Olech, A.; Kaźmierczak, T. Modele Partycypacji Publicznej. In Partycypacja Publiczna. O Uczestnictwie Obywateli w Życiu Wspólnoty Lokalnej; Olech, A., Ed.; Fundacja Instytut Spraw Publicznych: Warszawa, Poland, 2011; pp. 100-111.

81. Sevenant, M.; Antrop, M. Transdisciplinary landscape planning: Does the public have aspirations? Experiences from a case study in Ghent (Flanders, Belgium). Land Use Policy 2010, 27, 373-386. [CrossRef]

82. Rydin, Y.; Pennington, M. Public Participation and Local Environmental Planning: The collective action problem and the potential of social capital. Local Environ. 2000, 5, 153-169. [CrossRef]

83. Faehnle, M.; Bäcklund, P.; Tyrväinen, L.; Niemelä, J.; Yli-Pelkonen, V. How can residents' experiences inform planning of urban green infrastructure? Case Finland. Landsc. Urban Plan. 2014, 130, 171-183. [CrossRef]

84. Lauriusz, N. Wprowadzenie do partycypacji społecznej w Polsce. In Partycypacja Społeczna w Polsce. Atlas Dobrych Praktyk; Ćwiklicki, M., Frączek, M., Eds.; Fundacja Gospodarki i Administracji Publicznej: Kraków, Poland, 2013.

85. Szczepańska, A.; Kaźmierczak, R.; Myszkowska, M. Virtual Reality as a Tool for Public Consultations in Spatial Planning and Management. Energies 2021, 14, 6046. [CrossRef]

86. Świdyński, J.; Świdyńska, N. Konsultacje Społeczne Jako Narzędzie Wspótpracy Obywateli z Samorzadem Gminnym na Przykładzie Olsztyna/Public Consultation as a Tool of Cooperation of Citizens with Local Municipality on Example of Olsztyn; Wrocław University of Economics: Wrocław, Poland, 2016. [CrossRef]

87. Dorokhina, Y. Public Consultations as a Vital Aspect of Effective Cooperation Between the Government and Civic Organisations in Ukraine. Rocz. Adm. Publicz 2017, 3, 380386. [CrossRef]

88. Masłyk, T. Obywatel w Społeczeństwie Informacyjnym: Teoria i Praktyka; Nomos: Kraków, Poland, 2010.

89. Raciborski, J. Obywatelstwo w Perspektywie Socjologicznej; PWN: Warszawa, Poland, 2011.

90. Przewłocka, J. Zaangażowanie Społeczne Polaków w Roku 2010: Wolontariat, Filantropia, 1\%. Raport Badań; Stowarzyszenie Klon/Jawor: Warszawa, Poland, 2011.

91. Mularska-Kucharek, M. Poczucie podmiotowości i aktywność organizacyjna mieszkańców Łodzi. Ruch Prawni Czy Ekon. Socjol. 2012, 74, 251-264. [CrossRef]

92. Kowalewski, M. Organizowanie Miejskiego Aktywizmu w Polsce: Przestrzeń Społeczna; Instytut Socjologii, Uniwersytet Szczeciński: Szczecin, Poland, 2013; pp. 1-26.

93. Nagórny, J. Solidarność i sprzeciw u podstaw uczestnictwa w życiu społecznym. Refleksje nad społecznym nauczaniem Jana Pawła II ze szczególnym uwzględnieniem adhortacji „Christifideles laici”. Rocz. Teol. 1992, 3, 9.

94. Derdziuk, A. Świadectwo wartości w polityce, Rozprawy i Artykuły. Forum Teol. 2010, 11, 35-50.

95. Klamut, R. Civic Activity as a Kind of Social Activity-Psychological Perspective. Studia Socjol. 2013, Nr 1, 187-203.

96. Young People and Active Citizenship in Post-Soviet Times. 2017. Available online: https://www.taylorfrancis.com/books/ edit/10.4324/9781315564005/young-people-active-citizenship-post-soviet-times-kerry-kennedy-beata-krzywosz-rynkiewiczanna-zalewska-kerry-kennedy (accessed on 8 November 2021).

97. Gadomska, W.; Antolak, M. Wybrane aspekty planistyczne lokalizacji elektrowni wiatrowych w województwie warmińskomazurskim. Archit. Kraj. 2014, 1, 102-113.

98. Wolsink, M. Undesired reinforcement of harmful 'self-evident truths' concerning the implementation of wind power. Energy Policy 2012, 48, 83-87. [CrossRef]

99. Bell, D.; Gray, T.; Haggett, C.; Swaffield, J. Re-visiting the 'social gap': Public opinion and relations of power in the local politics of wind energy. Environ. Polit. 2013, 22, 115-135. [CrossRef]

100. McLachlan, C. Technologies in Place: Symbolic Interpretations of Renewable Energy. Sociol. Rev. 2009, 57, 181-199. [CrossRef]

101. Kempton, W.; Firestone, J.; Lilley, J.; Rouleau, T.; Whitaker, P.; Wenczel, A.; Jarvis, C.A.R.; Butterfield, S.; Mahony, A.B. The Offshore Wind Power Debate: Views from Cape Cod. Coast. Manag. 2005, 33, 119-149. [CrossRef]

102. Burningham, K.; Barnett, J.; Walker, G.P. An Array of Deficits: Unpacking NIMBY Discourses in Wind Energy Developers' Conceptualizations of Their Local Opponents. Soc. Nat. Resour. 2014, 28, 246-260. [CrossRef] 
103. Haggett, C. Understanding public responses to offshore wind power. Energy Policy 2011, 39, 503-510. [CrossRef]

104. Kemp, R. Why Not in My Backyard? A Radical Interpretation of Public Opposition to the Deep Disposal of Radioactive Waste in the United Kingdom. Environ. Plan. A Econ. Space 1990, 22, 1239-1258. [CrossRef]

105. Irwin, A.; Simmons, P.; Walker, G.P. Faulty Environments and Risk Reasoning: The Local Understanding of Industrial Hazards. Environ. Plan. A Econ. Space 1999, 31, 1311-1326. [CrossRef]

106. Gibson, T.A. NIMBY and the Civic Good. City Community 2005, 4, 381-401. [CrossRef]

107. Wexler, M. A sociological framing of the NIMBY (not-in-my-backyard) syndrome. Int. Rev. Modern Sociol. 1996, 26, 91-110.

108. Wright, N.; Nerlich, B. Use of the deficit model in a shared culture of argumentation: The case of foot and mouth science. Public Underst. Sci. 2006, 15, 331-342. [CrossRef] 